University of Nebraska - Lincoln

DigitalCommons@University of Nebraska - Lincoln

\title{
Potential for Transport of Boll Weevils (Coleoptera: Curculionidae) to the Cotton Gin within Cotton Modules
}

Thomas W. Sappington

USDA-ARS, tsapping@iastate.edu

Alan D. Brashears

USDA-ARS

Megha N. Parajulee

Texas A\&M University

Stanley C. Carroll

Texas A\&M University

Mark D. Arnold

Texas A\&M University

See next page for additional authors

Follow this and additional works at: https://digitalcommons.unl.edu/usdaarsfacpub

Part of the Agricultural Science Commons

Sappington, Thomas W.; Brashears, Alan D.; Parajulee, Megha N.; Carroll, Stanley C.; Arnold, Mark D.; Norman, John W. Jr.; and Knutson, Allen E., "Potential for Transport of Boll Weevils (Coleoptera: Curculionidae) to the Cotton Gin within Cotton Modules" (2004). Publications from USDA-ARS / UNL Faculty. 724.

https://digitalcommons.unl.edu/usdaarsfacpub/724

This Article is brought to you for free and open access by the U.S. Department of Agriculture: Agricultural Research Service, Lincoln, Nebraska at DigitalCommons@University of Nebraska - Lincoln. It has been accepted for inclusion in Publications from USDA-ARS / UNL Faculty by an authorized administrator of DigitalCommons@University of Nebraska - Lincoln. 


\section{Authors}

Thomas W. Sappington, Alan D. Brashears, Megha N. Parajulee, Stanley C. Carroll, Mark D. Arnold, John W. Norman Jr., and Allen E. Knutson 


\title{
Potential for Transport of Boll Weevils (Coleoptera: Curculionidae) to the Cotton Gin within Cotton Modules
}

\author{
THOMAS W. SAPPINGTON, ${ }^{1}$ ALAN D. BRASHEARS, ${ }^{2}$ MEGHA N. PARAJUlEE, ${ }^{3}$ \\ STANLEY C. CARROLL, ${ }^{3}$ MARK D. ARNOLD, ${ }^{3}$ JOHN W. NORMAN, JR., ${ }^{4}$ aND ALLEN E. KNUTSON ${ }^{5}$
}

USDA-ARS, Kika de la Garza Agricultural Research Center, 2314 E. Highway 83, Weslaco, TX 78596

J. Econ. Entomol. 97(3): 934-940 (2004)

\begin{abstract}
There is concern that cotton gins located in boll weevil, Anthonomus grandis grandis Boheman, eradication zones serving customers in adjacent infested zones may serve as a site for boll weevil reintroductions if weevils are transported alive inside cotton modules. We surveyed fields in three distinct areas of Texas and found that weevils can be present in large numbers in cotton fields that have been defoliated and desiccated in preparation for harvest, both as free adults and as immatures inside unopened bolls. Harvested cotton taken from module builders indicated that $\approx 100-3,700$ adult boll weevils were packed inside modules constructed at the sampled fields. Marked weevils were forced through a laboratory field cleaner (bur extractor) commonly mounted on stripper-harvesters, and $14 \%$ were recovered alive in the seed cotton fraction and lived at least to $24 \mathrm{~h}$. Survival of weevils placed inside modules declined over time up to $7 \mathrm{~d}$, but the magnitude of the decline varied with experimental conditions. In one experiment, $91 \%$ of the weevils survived to $7 \mathrm{~d}$, whereas under harsher environmental conditions, only $11 \%$ survived that long. Together, our results indicate that when cotton is harvested in an infested area, boll weevils likely will be packed alive into cotton modules, and many will still be alive by the time the module is fed into the gin, at least up to $7 \mathrm{~d}$ after the module's construction.
\end{abstract}

KEY WORDS Anthonomus grandis grandis, boll weevil, cotton gin, cotton module, eradication

THE BOLL WEEVIL, Anthonomus grandis grandis Boheman, has been eradicated from most of the southeastern and far western cotton production regions of the United States, and current programs are active in large parts of the central Cotton Belt (Grefenstette and El-Lissy 2003). There are several areas in the United States where zones that have achieved eradication or significant suppression share a border with a zone where weevil populations are still high (Allen et al. 2003, Grefenstette and El-Lissy 2003). Some of these still-infested areas have been in an active eradication program for only a short time, whereas others have yet to organize a program. Responding to a reinfestation is very expensive, so preventing and detecting reintroductions of weevils in eradicated or suppressed

Mention of trade names or commercial products in this article is solely for the purpose of providing specific information and does not imply recommendation or endorsement by the U.S. Department of Agriculture.

${ }^{1}$ USDA-ARS-CICGRU, Genetics Bldg., c/o Insectary, Iowa State University, Ames, IA 50011. E-mail: tsapping@iastate.edu.

${ }^{2}$ USDA-ARS-CPPRU, Lubbock, TX 79401.

${ }^{3}$ Texas Agricultural Experiment Station, Texas A\&M University, Lubbock, TX 79401.

${ }^{4}$ Texas Agricultural Extension Service, Texas A\&M University, Weslaco, TX 78596

${ }^{5}$ Texas Agricultural Extension Service, Texas A\&M University, Dallas, TX 75252 zones is a high priority. Boll weevils disperse naturally (Guerra 1986, 1988; Jones et al. 1992; Raulston et al. 1996) and migration from infested zones can slow progress in neighboring eradication zones (Allen et al. 2001 ). With movement by flight, little can be done to reduce the risk of reintroduction in the suppressed zone other than to remain vigilant until the nearby infested area advances in its eradication efforts. However, reintroductions can occur through human-mediated transport, and it is in this arena that adoption of preventive measures can have an impact.

We began a large cooperative study in 2000 to determine the potential for gins located in advanced eradication zones to serve as loci of boll weevil reintroductions through their service to customers harvesting cotton in nearby infested areas. The economic consequences of reinfestation are so great in an advanced or eradicated zone that the political pressures to prohibit movement of potentially infested cotton across its borders can become correspondingly great. At the same time, there are negative economic repercussions to the affected gins and growers if such movement is halted, so there is no desire to take unnecessary regulatory actions. Our research was initiated with the goal of determining the threats posed by module transport, gin sites, and gin products to weevilfree or nearly eradicated zones, so that minimally 
intrusive regulatory measures can be designed without endangering weevil-free areas.

The purpose of the study reported here was to determine whether live boll weevils can be packed into cotton modules during harvest and to determine the survival rate of weevils inside modules over time. Weevils transported within modules eventually will be fed into the gin, from which some may potentially escape to reinfest the surrounding area. Results of experiments examining survival through the ginning process will be reported elsewhere (see Sappington et al. 2003; Brashears et al. 2002 for preliminary findings). We surveyed defoliated cotton fields in three ecologically distinct areas of Texas for the presence of live weevils that might be picked up by the harvester. We had three main objectives. Our first objective was to estimate how many live weevils were packed into modules from the fields surveyed, either as free adults or enclosed as immatures and teneral adults in unopened bolls. If few or no weevils reach the gin alive in harvested cotton, then the ability to survive ginning machinery becomes less important. Our second objective was to determine the survival rate of weevils forced through field cleaners (also known as bur extractors), which are often mounted on stripper harvesters to remove some of the foreign matter in the cotton as it is harvested. Growers using field cleaners presumably produce modules with fewer weevils packed inside than those without cleaners, but the magnitude of the difference is unknown. Our third objective was to examine survival of weevils packed at different depths in a module over time. A module may remain in the field or gin yard for several days before it is ginned, and the number of live weevils introduced to the gin will depend on the relationship between mortality and length of time spent in the module. Different depths were tested because the weight of cotton in a packed module is substantial and could affect mortality.

\section{Materials and Methods}

Presence of Boll Weevils in Defoliated Cotton Fields. Defoliated cotton fields were surveyed immediately before harvest to estimate the numbers of boll weevil available for collection by the cotton picker or stripper. The experiment was conducted in three regions of Texas in 2001: the subtropical Lower Rio Grande Valley near Weslaco; the Northern Blacklands near Waxahachie; and the Southern High Plains near Lubbock. Samples were taken from fields near Weslaco and Waxahachie in 2002. Adult boll weevils were sampled by beat bucket in four defoliated cotton fields in each region. A 25-m stretch of each of five rows was sampled per field. The rows were chosen to be roughly equidistant from each other and from the parallel edges of the field. Samples were taken from each plant along the 25-m stretch by forcing as much of the plant as possible into a white 19-liter bucket and vigorously shaking it. Any plant debris falling into the bucket was carefully examined before removal, and any weevils recovered were placed in a vial and saved for future analysis of cuticular hydrocarbon profiles for age estimation (Sappington et al. 2000; results to be reported elsewhere). Beat-bucketing is a relative sampling method for boll weevils, which may underestimate the number of weevils present (Raulston et al. 1998).

In many fields, green or incompletely opened bolls were common in the defoliated field, and it is possible that weevil-infested bolls could be packed into modules and serve as a source of emerging adults at the gin. All such bolls were removed from an adjacent $25 \mathrm{~m}$ of row and were dissected to determine percentage of infestation and the life stage distribution of infesting weevils. When there were $>100$ bolls from a row, a random subsample of 100 was dissected. All samples were taken $0-1 \mathrm{~d}$ before harvest.

Presence of Boll Weevils in Harvested Cotton. The four fields at each location were harvested by pickerharvesters (Weslaco) or stripper-harvesters (Waxahachie and Lubbock). In each field, 5-10 (2001) or 10 (2002) samples of seed cotton were collected in 29liter paper bags from active module builders and represented at least two different dumps of the harvesters. Each bag filled to the top constituted a sample, and usually three to four samples were taken per dump. The cotton was gathered by hand when the module builder was full enough that newly dumped cotton could be reached from the edge of the frame behind the cab. The cotton in these samples represented harvest from several places in the field, because the space needed for a the harvester to turn at the end of the field led to a harvesting pattern that was always more complex than simply going back-and-forth along adjacent swaths. In addition, natural mixing occurs in the harvester bin, during the dump as the harvester moves forward and backward, and when the dumped cotton is smoothed out by the tamper operator before tamping begins.

The bags were returned to the laboratory and weighed. They were sealed and stored in the laboratory at room temperature $\left(\approx 22^{\circ} \mathrm{C}\right)$ until they could be processed. In the case of the 2002 samples, 10 weevils captured in pheromone traps in Weslaco were killed by freezing, marked on one elytron with a small spot of paint, and mixed into the seed cotton in each bag to serve as controls for our ability to find natural weevils. The cotton in the bags was sorted by hand to recover marked and unmarked adult weevils. Boll weevils per module were estimated from the number of unmarked weevils recovered per kilogram of sampled seed cotton, assuming a 6,810-kg (15,000-lb) module.

Survival through a Field Cleaner. We tested survival of known numbers of marked adult boll weevils passed through a 1.53-m (5-foot) John Deere field cleaner mounted at the USDA-ARS Cropping Systems Research Laboratory in Lubbock. The weevils were obtained from the culture maintained at the USDAAPHIS Mission Plant Protection Center in Mission, TX.

Encapsulated Adults. A larva feeding within a boll creates an oblong hollow chamber in which to pupate. This pupal cell consists of tightly packed larval frass, 
which is somewhat hard, but brittle. When sorting through the seed cotton sampled from modules, we discovered a few newly eclosed adult weevils in intact or partially intact pupal cells. Because the pupal cells are roughly the size and shape of a cotton seed, we deemed it important, in the context of our overall project, to test the possibility of weevil survival in pupal cells up through the point in the ginning process where seed or motes are removed from the lint. However, we found it impossible to collect natural pupal cells in the numbers needed for our experiments. Instead, we encased adult weevils in empty gelatin capsules (No. 4 size, T.U.B. Enterprises, Almonte, Ontario, Canada), which are of a size and shape similar to natural cells. Before use, the capsules were baked at $65^{\circ} \mathrm{C}$ under a vacuum of $760 \mathrm{mmHg}$ for $24 \mathrm{~h}$, and held thereafter in a sealed plastic bag with desiccant material to make them fairly brittle. Although the physical properties of these simulated pupal cells differ from natural pupal cells in many respects, we judged that they would provide a conservative estimate of mortality in the field cleaner and ginning processes, because our observations indicated they offer greater protection than the natural cells.

Survival Test. Free adult boll weevils (300) and 100 adults enclosed in simulated pupal cells were marked with orange and green fluorescent powder, respectively, and uniformly distributed into $11.4 \mathrm{~kg}(25 \mathrm{lb})$ of harvested cotton spread evenly along a 6.1-m (20foot) conveyor belt placed on a catwalk over the field cleaner. The weevil-seeded cotton was fed by gravity into the field cleaner from the conveyor belt. Both the cleaned seed cotton fraction and the waste were inspected in their entirety for dead and live boll weevils under a blacklight. Free weevils recovered alive were placed together in a petri dish containing a cotton wick soaked in water and examined after $24 \mathrm{~h}$ for continued survival. Weevils recovered alive in simulated pupal cells, were returned to the capsule and placed together in a petri dish (without water) and examined after $24 \mathrm{~h}$ for continued survival. Twenty marked free adults and 20 marked weevils in simulated pupal cells were kept in a petri dish as controls for mortality. Mortality among controls was very low in all cases, so the data are not presented. The experiment was replicated five times.

Boll Weevil Mortality over Time inside Cotton Modules. Weevils were placed in cotton pouches, inserted inside a cotton module at different locations, and left for specified times to examine survival. Groups of 20 weevils of unknown age (but usually between 1 and 3 wk old), obtained from the USDA-APHIS rearing facility in Mission, were placed between two bats of seed cotton, separated by a sheet of paper, inside 33 by $36-\mathrm{cm}$ woven cotton pouches. After introduction of the weevils, the sheet of paper was removed and the pouch sealed with staples. On each side of two cotton modules at the research laboratory in Lubbock, a set of three pouches was inserted $\approx 15 \mathrm{~cm}$ in depth in each of three locations in the module-high, middle, and low ( $\approx 55,100$, and $155 \mathrm{~cm}$ from the top, respectively) - by briefly lifting a portion of the module with a fork-lift. From each set of three pouches, one was removed after each of 1,3 , and $7 \mathrm{~d}$. In addition, there was one control pouch for each module side (replication) and duration tested. Control pouches were placed on a laboratory bench and held at room temperature. After removal, each seed cotton bat was searched for weevils which were classified as alive or dead (no movement when the snout was pinched). The experiment was conducted twice, in October 2002 and March 2003. In the first run, a torrential rain on the same day as insertion of the bags resulted in some of the bags and their contents becoming wet. In the second run, there were no rain events and all bags remained dry. On 1 day during both experiments, temperatures within the module near each of the sets of three bags were taken with a Fluke 73 Series multimeter (Fluke Corporation, Everett, WA) run at 300 $\mathrm{mV}$ and equipped with an Omega Type $\mathrm{K}$ temperature probe (Omega Engineering, Stamford, CT).

Because of differences in precipitation and internal module temperatures, and the consequent differences in test conditions, the two runs were analyzed separately. Differences in percentage survival due to location within the module between days were tested by analysis of variance (ANOVA), with location, days, and replication as main effects, and all pairwise interactions examined. Percentage data were arcsine square-root transformed for analyses but are presented as untransformed means for clarity. Means were separated by the Tukey's honestly significant difference (HSD) test $(\alpha=0.05)$. Differences in percent survival in the experimental and control pouches for each time treatment were evaluated by a twosample $t$-test.

\section{Results and Discussion}

Presence of Boll Weevils in Defoliated Cotton Fields. Adult boll weevils were recovered by beat bucket in surprisingly high numbers from defoliated cotton just before harvest, especially in Weslaco in both years and Waxahachie in 2002 (Table 1). In Waxahachie and Lubbock in 2001, free adult weevils were present but in much lower numbers. It is not entirely clear why adult weevils are present in cotton after defoliation. It is possible that green bolls remaining on the plants (Table 1) provided a food source in areas where very little green cotton remained in the fields. Mean infestation of bolls in defoliated fields ranged from 0 to $28 \%$ (Table 1 ). The bolls in Lubbock in 2001 were incompletely opened, dry, and not green, but nevertheless housed live boll weevils of all stages. It seems likely that many of the adult weevils recovered in the beat bucket samples were newly emerged and had not yet dispersed from the defoliated field. Ongoing analyses of cuticular hydrocarbon profiles, which can be used to estimate weevil age (Sappington et al. 2000), taken from weevils collected in the beat bucket samples will permit a more direct test of this hypothesis.

Presence of Boll Weevils in Harvested Cotton. Samples of harvested cotton were examined for the pres- 
Table 1. Potential for mature and immature boll weevils (BW) to be found in defoliated cotton fields at time of harvest

\begin{tabular}{|c|c|c|c|c|c|c|c|c|c|c|}
\hline \multirow{2}{*}{ Year } & \multirow{2}{*}{ Loc } & \multirow{2}{*}{$\mathrm{BW} / 25 \mathrm{~m}$} & \multirow{2}{*}{$\mathrm{BW} / \mathrm{ha}^{a}$} & \multirow{2}{*}{ Bolls / 25m } & \multirow{2}{*}{ Bolls/ha ${ }^{a}$} & \multirow{2}{*}{$\%$ Infested } & \multicolumn{3}{|c|}{ Stage } & \multirow{2}{*}{$\begin{array}{l}\text { Teneral } \\
\text { adults/ha }\end{array}$} \\
\hline & & & & & & & $\% \mathrm{~L}$ & $\% \mathrm{P}$ & $\% \mathrm{~A}$ & \\
\hline \multirow[t]{3}{*}{2001} & Wes & $6.2 \pm 1.62$ & 2,480 & $148.4 \pm 37.85$ & 59,360 & $3.9 \pm 0.64$ & $49.3 \pm 10.66$ & $20.5 \pm 9.08$ & $32.5 \pm 14.66$ & 304 \\
\hline & Wax & $0.2 \pm 0.05$ & 80 & $3.5 \pm 0.65$ & 1,400 & 0 & & & & 0 \\
\hline & Lub & $0.3 \pm 0.16$ & 120 & $46.4 \pm 20.06$ & 18,560 & $4.5 \pm 2.63$ & $26.3 \pm 14.50$ & $15.0 \pm 14.01$ & $59.0 \pm 20.4$ & 199 \\
\hline \multirow[t]{2}{*}{2002} & Wes & $10.7 \pm 1.84$ & 4,280 & $136.1 \pm 59.68$ & 54,400 & $27.8 \pm 12.64$ & $62.0 \pm 29.24$ & $19.0 \pm 6.11$ & $19.1 \pm 9.45$ & 1,170 \\
\hline & Wax & $4.1 \pm 1.28$ & 2,722 & $97.3 \pm 17.64$ & 38,920 & $4.7 \pm 1.04$ & $8.1 \pm 5.90$ & $20.1 \pm 6.35$ & $71.9 \pm 8.50$ & 532 \\
\hline
\end{tabular}

Mean \pm SE numbers of boll weevils recovered by beat bucket $(\mathrm{BW} / 25 \mathrm{~m})$ and in unopened bolls from defoliated cotton $(n=20)$ near Weslaco (Wes), Waxahachie (Wax), and Lubbock (Lub), TX. Mean percentage of bolls infested with live boll weevils, and life stage distribution among those weevils found infesting bolls are indicated: L, larvae; P, pupae; and A, adults.

${ }^{a}$ Values were calculated by extrapolation, based on the number of row-meters in a hectare.

ence of intact weevils. In total, $97.4 \%$ of marked control weevils were recovered from the bags of seed cotton, suggesting that very few unmarked weevils were overlooked. Unmarked adult weevils were recovered from most samples of seed cotton from the module builders, and their numbers indicated that an average of 341-7,219 weevils per location per year was packed into individual modules (Table 2 ). The estimated number of weevils packed within $1 \mathrm{~cm}$ of an exposed module surface, $5-100$ (i.e., $1.4 \%$ of total weevils estimated to be in a module), represents potential dispersants before entering the gin.

Sorting through the sampled cotton was labor-intensive and required several months to complete, so almost all of the recovered weevils were dead by the time they were found. However, live unmarked weevils were occasionally found and had remained alive in the sample bags from 45 to $109 \mathrm{~d}$. Survival for this length of time without food suggests that some of the weevils may have been in diapause when harvested. No bolls were found in any of the samples. However, bolls were visible in low numbers on the surface of the modules and were probably not encountered due to the small amount of cotton sampled relative to the total size of a module. In the 2002 Weslaco samples, two cotton squares (flower buds) were recovered that were infested with adult weevils that had not yet emerged.

Table 2. Potential for boll weevils $(\mathrm{BW})$ to be packed alive into modules, including possible dispersants packed near module surface

\begin{tabular}{lcccc}
\hline \hline Year & Location & BW $/ \mathrm{kg}$ & $\mathrm{BW} / \mathrm{mod}^{a}$ & $\begin{array}{c}\text { BW near } \\
\text { surface }^{b}\end{array}$ \\
\hline 2001 & Wes & $0.19 \pm 0.110$ & 1294 & 18 \\
& Wax & $0.05 \pm 0.031$ & 341 & 5 \\
& Lub & $0.51 \pm 0.293$ & 3473 & 48 \\
2002 & Wes & $1.06 \pm 0.691$ & 7219 & 100 \\
& Wax & $0.33 \pm 0.077$ & 2247 & 31 \\
\hline
\end{tabular}

Weevils (mean $\pm \mathrm{SE}$ ) recovered per kilogram $(\mathrm{BW} / \mathrm{kg})$ of harvested seed cotton sampled from module builders immediately after harvester dumping in fields near Weslaco (Wes), Waxahachie (Wax), and Lubbock (Lub), TX.

${ }^{a}$ Calculated based on $6,810-\mathrm{kg}(15,000-\mathrm{lb})$ module. Values were calculated by extrapolation.

${ }^{b}$ Number of weevils calculated to be packed within $1 \mathrm{~cm}$ of the module surface (excluding bottom), based on module of dimensions 2.44 by 2.75 by $9.76 \mathrm{~m}$ ( 8 by 9 by 32 feet) (width by height by length). Values were calculated by extrapolation.
Survival through a Field Cleaner. Much of the cotton grown in western states such as Texas and New Mexico is stripper-harvested, a method that improves the total amount of fiber gleaned from a field, but which also increases the amount of foreign material such as burs, sticks, and soil picked up by the harvester (Williford et al. 1994). The use of field cleaners (bur extractors), mounted on stripper-harvesters to remove some of this material during harvesting is becoming increasingly popular (Nelson et al. 2000, Baker et al. 2001), with $\approx 75-80 \%$ of the cotton strippers in the Texas High Plains being so equipped. In essence, a field cleaner consists of a two-saw stick machine (Baker and Brashears 2000), similar to those found in the gin (Baker et al. 1994) but more compact, and is the first mechanical cleaning device through which harvested live weevils may pass. Briefly, the field cleaner uses two 33-cm (13-inch)-diameter, 1.53-m (5-foot)-long cylinders, on which coarse-toothed channel-saws are mounted to grab the seed cotton. The first or main saw cylinder slings the seed cotton against grid bars (2.54-cm [1-inch]-diameter pipe) mounted around the outside, so that foreign matter is separated from it. The second saw cylinder reclaims seed cotton removed with the foreign matter and returns it to the cleaned seed cotton, which is removed from the saw cylinders by doffing brushes. The field cleaner removes $55-60 \%$ of the foreign matter from the seed cotton. The separated cotton trash (including burs and sticks) is dropped on the ground, whereas the cleaned seed cotton is eventually dumped from the harvester basket into a module builder.

Our results indicate that about two-thirds to threefourths of the free adults and weevils in pupal cells picked up at harvest will be removed by a field cleaner and returned to the ground with the trash (Table 3). Of these, about one-half to two-thirds survived at least $24 \mathrm{~h}$ in our experiment. Live weevils also are expected to make it through the field cleaner to be packed into the module. Approximately $14 \%$ of free adults and $4 \%$ of encapsulated weevils fed into the field cleaner were recovered alive in the seed cotton and lived at least $24 \mathrm{~h}$. Approximately $9-15 \%$ of the marked weevils were not recovered dead or alive (Table 3) and were presumed to have been broken up by the machinery. Thus, a field cleaner is expected to reduce, but not eliminate, the number of live weevils transported in a module to the cotton gin. 
Table 3. Survival of boll weevils passing through a laboratory-mounted field cleaner

\begin{tabular}{|c|c|c|c|c|c|}
\hline Treatment & Fraction & $\begin{array}{c}\text { Total } \\
\text { recovered }^{a}\end{array}$ & $\begin{array}{c}\text { Recovered } \\
\text { dead }\end{array}$ & $\begin{array}{l}\text { Recovered } \\
\text { alive }\end{array}$ & $\begin{array}{c}\text { Still alive } \\
\text { at } 24 \mathrm{~h}\end{array}$ \\
\hline Free adult $(n=300 /$ & Seed cotton & $87.4 \pm 4.19$ & $15.6 \pm 1.50$ & $71.8 \pm 4.37$ & $41.4 \pm 5.10$ \\
\hline replicate) & Trash & $187.0 \pm 7.86$ & $22.4 \pm 2.73$ & $164.6 \pm 7.00$ & $94.4 \pm 8.66$ \\
\hline Simulated pupal cell & Seed cotton & $11.6 \pm 1.63$ & $3.4 \pm 1.12$ & $8.2 \pm 1.46$ & $3.6 \pm 0.81$ \\
\hline$(n=100 /$ replicate $)$ & Trash & $73.4 \pm 2.77$ & $6.6 \pm 1.03$ & $66.8 \pm 3.01$ & $42.2 \pm 1.43$ \\
\hline
\end{tabular}

Mean \pm SE number of marked, free adult boll weevils, and marked, encapsulated adults recovered in the seed cotton and trash (bur) fractions $(n=5)$.

${ }^{a} 91.5 \pm 2.06 \%$ of free adults and $85.0 \pm 3.32 \%$ of encapsulated adults were recovered in total.

Boll Weevil Mortality over Time inside Cotton Modules. Harvested cotton is usually stored in the form of a free-standing stack, or module, until it can be ginned (Lalor et al. 1994). The length of time a module must be stored until ginning can vary greatly, but during peak harvest a 1 -wk interval is not unusual. Boll weevils were placed at different locations within modules to determine their survival over time, up to $7 \mathrm{~d}$. The experiment was run twice, under differing environmental conditions. In the first experiment, torrential rains forcefully striking the sides of the modules resulted in some of the cotton pouches getting moist or even wet. In addition, temperatures inside the module near the pouches were very high (Table 4 ), averaging $29.1^{\circ} \mathrm{C}$. In the second experiment, pouches remained dry, and temperatures within the module were significantly cooler (Table 4$)(t=13.24 ; \mathrm{df}=22$; $P<0.0001$ ), averaging $15.2^{\circ} \mathrm{C}$.

In the first experiment, there were no significant effects of pouch location $(F=0.16 ; \mathrm{df}=2,12 ; P=0.85)$ or replication $(F=1.89 ; \mathrm{df}=3,12 ; P=0.18)$ on survival of weevils in pouches (Table 5). None of the two-way interactions were significant. Survival was significantly affected by the number of days in the module $(F=92.63 ; \mathrm{df}=2,12 ; P<0.0001)$, with survival declining significantly each day (Table 5). Survival was relatively high up to $3 \mathrm{~d}$ in the module and was not different than in the controls, but was much less by $7 \mathrm{~d}$ (Table 5). Although weevil survival in the control pouches also declined with days $(F=7.56$, $\mathrm{df}=2,9, P=0.01$ ), survival in the module for $7 \mathrm{~d}$ was significantly less than in the corresponding controls (Table 5) $(t=3.24, \mathrm{df}=6, P=0.02)$. In the second

Table 4. Differential microenvironments within cotton modules during two different experimental tests of weevil survival in inserted pouches, Lubbock, TX

\begin{tabular}{cccc}
\hline Date & $\begin{array}{c}\text { Relative } \\
\text { location }^{a}\end{array}$ & $\begin{array}{c}\text { Mean } \pm \mathrm{SE} \\
\text { Distance }(\mathrm{cm}) \text { from } \\
\text { top of module }\end{array}$ & $\begin{array}{l}\text { Mean } \pm \mathrm{SE} \\
\text { temp }\left({ }^{\circ} \mathrm{C}\right)^{b}\end{array}$ \\
\hline Oct. 2002 & High & $53 \pm 6.3$ & $27.8 \pm 1.05 \mathrm{a}$ \\
& Mid & $84 \pm 10.5$ & $30.3 \pm 2.45 \mathrm{a}$ \\
Mar. 2003 & Low & $143 \pm 10.9$ & $29.3 \pm 1.29 \mathrm{a}$ \\
& High & $57 \pm 6.4$ & $16.9 \pm 0.66 \mathrm{a}$ \\
& Mid & $114 \pm 3.3$ & $14.9 \pm 0.54 \mathrm{~b}$ \\
& Low & $166 \pm 8.8$ & $13.9 \pm 0.24 \mathrm{~b}$ \\
\hline
\end{tabular}

Mean temperatures inside module near pouches $(n=4)$.

${ }^{a}$ Describes relative height of pouch placement within a module.

${ }^{b}$ Means followed by the same lowercase letter within a column for each date are not significantly different ( $\alpha=0.05$, Tukey's HSD test). experiment, survival was much higher through $7 \mathrm{~d}$ in both the controls and the treatment pouches, which did not differ significantly for any time interval (Table $5)$. There were no significant effects of pouch location $(F=1.62 ; \mathrm{df}=2,12 ; P=0.24)$ or replication $(F=0.05$; $\mathrm{df}=3,12 ; P=0.98)$ on weevil survival, nor were any of the two-way interactions significant. Survival was significantly affected by the number of days in the module $(F=16.13 ; \mathrm{df}=2,12 ; P=0.0004)$. Survival in the module and in the controls for $7 \mathrm{~d}$ was significantly less than that for one or $3 \mathrm{~d}$, but the difference was not great (Table 5).

Thus, both experiments indicate that survival of weevils packed inside a module decreases over time, but the magnitude of the decrease can differ greatly depending on the initial health of the weevils and the environmental conditions inside the module. Although not tested in this study, diapause status of weevils would be expected to influence longevity of natural weevils inside a module. The high mortality observed in the first experiment was due in part to a somewhat poorer stock of weevils than in the second experiment, as revealed by survival over time in the control pouches (Tables 5 and 6). Survival to $7 \mathrm{~d}$ in a module was less than that of the controls in the first experiment, but not the second. This finding and the lack of differences in survival depending on depth of the pouches in the module, indicate that pressures inside the module do not affect survival per se, at least to $7 \mathrm{~d}$. In module builders, seed cotton is compacted to $\approx 17.7 \mathrm{~kg} / \mathrm{m}^{3}\left(12 \mathrm{lb} / \mathrm{ft}^{3}\right)$ so that it can retain its integrity after removal of the builder (Lalor et al. 1994), but Brashears et al. (2002) observed 100\% survival of weevils in a bale press at pressures of 22.3 $\mathrm{kg} / \mathrm{m}^{3}\left(15 \mathrm{lb} / \mathrm{ft}^{3}\right)$ and below. Instead, it is likely that differential environmental conditions were responsible for the differential survival in the two experiments. High temperatures, high moisture, or both may have contributed to higher mortality in the first experiment. Nevertheless, even in the case of less robust weevils placed under the more stressful environmental conditions of the first experiment, $11 \%$ survived $7 \mathrm{~d}$ inside the modules.

In conclusion, the results of this study indicate that boll weevils are likely to be present in defoliated and desiccated cotton fields and that one can expect weevils to be picked up by the harvester and packed alive into cotton modules, often in large numbers. The weevils packed into modules will be mainly free adults, but 
Table 5. Boll weevil survival over time inside a cotton module

\begin{tabular}{|c|c|c|c|c|c|c|}
\hline \multirow{2}{*}{ Date } & \multirow{2}{*}{ Day } & \multicolumn{3}{|c|}{ Relative location } & \multirow{2}{*}{ All location ${ }^{b, c}$} & \multirow{2}{*}{ Control $^{b, c}$} \\
\hline & & High & Middle & Low & & \\
\hline \multirow[t]{3}{*}{ Oct. 2002} & 1 & $97.4 \pm 1.48$ & $98.4 \pm 1.56$ & $93.8 \pm 4.73$ & $96.6 \pm 1.83 \mathrm{aA}$ & $94.7 \pm 5.26 \mathrm{aA}$ \\
\hline & 3 & $81.3 \pm 9.66$ & $71.1 \pm 13.8$ & $81.4 \pm 11.1$ & $78.1 \pm 9.17 \mathrm{bA}$ & $91.3 \pm 5.15 \mathrm{aA}$ \\
\hline & 7 & $2.5 \pm 2.50$ & $18.8 \pm 13.0$ & $11.3 \pm 6.57$ & $11.0 \pm 3.58 \mathrm{cA}$ & $52.5 \pm 12.7 \mathrm{bB}$ \\
\hline \multirow[t]{3}{*}{ Mar. 2003} & 1 & 100 & 100 & $98.8 \pm 1.25$ & $99.6 \pm 0.42 \mathrm{aA}$ & $100 \mathrm{aA}$ \\
\hline & 3 & 100 & 100 & 100 & $100 \mathrm{aA}$ & $96.0 \pm 2.44 \mathrm{aA}$ \\
\hline & 7 & $87.5 \pm 4.33$ & $97.4 \pm 1.52$ & $89.8 \pm 3.63$ & $91.5 \pm 0.69 \mathrm{bA}$ & $84.7 \pm 3.67 \mathrm{bA}$ \\
\hline
\end{tabular}

Mean \pm SE percentage weevils recovered alive from sealed pouches after indicated number of days when placed at different relative locations within a cotton module, during experiments conducted in two months $(n=4)$.

${ }^{a}$ Describes relative height of pouch placement within a module.

${ }^{b}$ Means followed by the same lowercase letter within a column for each date are not significantly different ( $\alpha=0.05$, Tukey's HSD test).

${ }^{c}$ All locations and Control means followed by the same uppercase letter within a row are not significantly different $(\alpha=0.05$, two-sample $t$-test).

they may also include adults inside pupal cells and inside infested fruit. In stripper-harvested cotton, a field cleaner will substantially reduce, but not eliminate, the number of live weevils entering the module builder to be transported to a gin site. Survival of weevils packed inside a module can be high, at least through $7 \mathrm{~d}$. There is some suggestion that high temperatures inside the module may reduce survival, but our data cannot resolve this possibility. Our results indicate that prolonged exposure to the pressures resulting from the weight of the packed cotton in a module is not a significant source of mortality. During module building, the harvested cotton is mechanically tamped down, and it is possible that this process may kill some weevils. However, it is unlikely that this is an important factor given the pressures weevils can survive in a bale press (unpublished data; Brashears et al. 2002, Hughs et al. 2002). Together, our results indicate that when cotton is harvested in an infested area, boll weevils likely will be packed alive into cotton modules, and many will still be alive by the time the module is fed into the gin, at least up to $7 \mathrm{~d}$ after the module's construction.

\section{Acknowledgments}

We thank Latha Bommireddy, Jesus Cabellero, Jr., Manuel Campos, Veronica Cardoza, Art Castro, Jimmy Castro, Andy Cranmer, Valentina Greenberg, Lanthia Jones, Ross Johnson, Anand Sapkota, R. B. Shrestha, Bill Turner, and Orlando Zamora for technical assistance, and Glen Moore for logistical help in Waxahachie. We thank A. C. Fuller and Marvin Fuller in Progreso, and Charlie Spaniel and Tim Harper in Waxahachie for kind cooperation and the use of fields and modules. Thank you to Leeda Wood for efforts in keeping us supplied with large numbers of laboratory-reared boll weevils. Funding was provided in part by grants IPM01-023 to $R$. Baker and T.W.S., and IPM02-004 to T.W.S. and A.D.B. from the Texas Department of Agriculture.

\section{References Cited}

Allen, C. T., L. W. Patton, L. E. Smith, and R. O. Newman. 2001. Texas boll weevil eradication update, pp. 934-936. In Proceedings of the Beltwide Cotton Conferences, 9-13 January, Anaheim, CA. National Cotton Council, Memphis, TN.
Allen, C. T., L. E. Smith, L. W. Patton, and R. O. Newman. 2003. Status of boll weevil eradication in Texas, pp. 1340 1345. In Proceedings of the Beltwide Cotton Conferences, 6-10 January, Nashville, TN. National Cotton Council, Memphis, TN.

Baker, R. V., and A. D. Brashears. 2000. Combined effects of field cleaning and lint cleaning on stripper harvested cotton, pp. 1616-1621. In Proceedings of the Beltwide Cotton Conferences, 4-8 January, San Antonio, TX. National Cotton Council, Memphis, TN.

Baker, R. V., W. S. Anthony, and R. M Sutton. 1994. Seed cotton cleaning and extracting, pp. 69-90. In W. S. Anthony and W. D. Mayfield [eds.], Cotton Ginners Handbook. U.S. Department of Agriculture, Agricultural Handbook No. 503.

Baker, R. V., G. A. Holt, and A. D. Brashears. 2001. Influence of stick machines on turnout and quality of stripper cotton, pp. 1361-1364. In Proceedings of the Beltwide Cotton Conferences, 9-13 January, Anaheim, CA. National Cotton Council, Memphis, TN.

Brashears, A. D., R. V. Baker, T. W. Sappington, S. Carroll, M. Arnold, and M. Parajulee. 2002. Boll weevil survival in baled lint, 5 pp. In Proceedings of the Beltwide Cotton Conferences, 8-12 January, Atlanta, GA. National Cotton Council, Memphis, TN.

Grefenstette, B., and O. El-Lissy. 2003. Boll weevil eradication update, pp. 131-141. In Proceedings of the Beltwide Cotton Conferences, 6-10 January, Nashville, TN. National Cotton Council, Memphis, TN.

Guerra, A. A. 1986. Boll weevil movement: dispersal during and after the cotton season in the Lower Rio Grande Valley of Texas. Southwest. Entomol. 11: 10-16.

Guerra, A. A. 1988. Seasonal boll weevil movement between northeastern Mexico and the Rio Grande Valley of Texas, USA. Southwest. Entomol. 13: 261-271.

Hughs, S. E., C. B. Armijo, and R. T. Staten. 2002. Boll weevil survival in the ginning system, $5 \mathrm{pp}$. In Proceedings of the Beltwide Cotton Conferences, 8-12 January, Atlanta, GA. National Cotton Council, Memphis, TN.

Jones, R. W., J. R. Cate, E. M. Hernandez, and R. T. Navarro. 1992. Hosts and seasonal activity of the boll weevil (Coleoptera: Curculionidae) in tropical and subtropical habitats of northeastern Mexico. J. Econ. Entomol. 85: 74-82.

Lalor, W. F., M. H. Willcutt, and R. G. Curley. 1994. Seed cotton storage and handling, pp. 16-25. In W. S. Anthony and W. D. Mayfield [eds.], Cotton Ginners Handbook, U. S. Department of Agriculture, Agricultural Handbook No. 503. 
Nelson, J., S. K. Misra, and A. Brashears. 2000. Costs associated with alternative cotton stripper-harvesting systems in Texas. J. Cotton Sci. 4: 70-78.

Raulston, J. R., T. J. Henneberry, J. E. Leggett, D. N. Byrne, E. Grafton-Cardwell, and T. F. Leigh. 1996. Short- and long-range movement of insects and mites, pp. 143-162. In E. G. King, J. R. Phillips, and R. J. Coleman [eds.], Cotton insects and mites: characterization and management. Cotton Foundation Reference Book Series, No. 3. The Cotton Foundation Publisher, Memphis, TN.

Raulston, J. R., D. W. Spurgeon, and A. N. Sparks, Jr. 1998. Influence of fruit on sampling and control of adult boll weevils in cotton. Southwest. Entomol. 23: 1-10.

Sappington, T. W., A. D. Brashears, M. N. Parajulee, S. C. Carroll, M. D. Arnold, J. W. Norman, Jr., A. E. Knutson, and R. V. Baker. 2003. Modules, gins, and the threat of boll weevil introductions: what we know so far, pp. 1329 1339. In Proceedings of the Beltwide Cotton Conferences, 6-10 January, Nashville, TN. National Cotton Council, Memphis, TN.

Sappington, T. W., O. R. Zamora, D. R. Nelson, and C. L. Fatland. 2000. Determining boll weevil age with cuticular hydrocarbon profiles, pp. 1167-1171. In Proceedings of the Beltwide Cotton Conferences, 4-8 January, San Antonio, TX. National Cotton Council, Memphis, TN.

Williford, J. R., A. D. Brashears, and G. L. Barker. 1994. Harvesting, pp. 11-16. In W. S. Anthony and W. D. Mayfield [eds.], Cotton ginners handbook, U.S. Department of Agriculture, Agricultural Handbook No. 503.

Received 6 August 2003; accepted 22 February 2004. 